\title{
Historický vývoj konceptů fámy a „veřejného míněni“
}

\author{
KATEŘINA SOUKALOVÁ*
}

The Historical Development of Concepts of Rumour and "Public Opinion"

\begin{abstract}
This article deals with the relationship between public opinion and rumour from ancient times, through the Middle Ages and right up to today. It willexamine the terms which were used and which often depended not just on aparticular author but usually an entire social class. The most often used terms to describe opinion, fama and existimatio, occurred in the speeches of politicians which were presented as the valuable opinions of the elite whereas the concepts opinio, rumor or sermo were considered as low value and unreliable opinions of plebeians to whom the ruling classes attributed the spreading and creation of rumours. The concept of fama, more often fama publica, indicated in the Middle Ages a local network of knowledge, a mechanism for the collective evaluation of an individual. In this sense it played an important role in the courts of law. The issue of rumours is common to all subesequent historical periods because public opinion usually both generated, and was supported, by rumour. The article also puts forward a hypothesis why the all-powerful fama dissapeared from the courtrooms, why it lost its significance and became purely a rumour.
\end{abstract}

Keywords: opinion; rumour; communication; reputation; community; law of Middle Ages

DOI: $10.14712 / 23363525.2015 .6$

„I o pověsti a veřejném mínění ŕíkají jedni, že je to souhlas obce a jakoby veřejné svědectví, druzí, že jsou to zprávy z nejistého pramene, které mají svůj původ v zlomyslnosti a za svůj vzrůst děkují lehkověrnosti a mohou postihnout každého, i člověka zcela nevinného, zásluhou lstivosti osobních nepřátel rozšiřujících nepravdy.“ Takto mluví o pověsti a „veřejném mínění" Marcus Fabius Quintilianus [1985: 212] a úryvek z jeho Základů rétoriky vystihuje téma této práce - vztah mezi fámou a „veřejným míněním“ a jejich pojímáním jak $\mathrm{v}$ dobách antiky, stř̌edověku, tak v renesanci, a to zejména v kontextu vnímání famy, mnohoznačného fenoménu tehdy zcela odlišného od toho, jak ho vnímáme dnes. Quintilianus tedy mluví o pověsti a „veřejném míněni “ ${ }^{1}$ - v latinském originále rumor a fama - o pojmech dnes prakticky totožných, tehdy ovšem naprosto rozdílných. Přestože to byly svým vlivem i významem pojmy odlišné, neexistovala mezi nimi jasná hranice a často bývaly zaměňovány, zejména v závislosti na společenské vrstvě mluvčího či vrstvě toho, o kom se mluví.

Pověst, neboli fáma, slovo latinského původu (fama), je odvozená od slovesa fari, znamenajíćího hovořit, povídat či mluvit, od čehož lze odvodit význam fámy jako ústně

* Mgr. Kateřina Soukalová, Fakulta humanitních studií Univerzity Karlovy v Praze, Pracoviště historické sociologie, U Kř́že 8, 15800 Praha 5 - Jinonice. Kontakt: kat.soukalova@seznam.cz.

1 V latinském originále Marca Fabia Quintiliana se objevuje pojem fama, který Václav Bahník přeložil do češtiny výrazem veřejné mínění. Tento pojem, tak jak ho vnímáme my dnes, se však ustanovil až mnohem později. Dnešnímu termínu veřejné mínění byl $\mathrm{v}$ antice $\mathrm{z}$ hlediska slovního základu bližší výraz opinio (o němž je ve stati taktéž pojednáno), který se v 18. století promítl i do francouzského výrazu opinion publique. Naopak slovo rumor je dnes veskrze spojováno s řečmi, obíhajícími mezi lidmi. Dnešní chápání pojmu fáma je tedy blízké, ne-li totožné s tím, co dnes označujeme jako rumor, zatímco v antice tomu tak ještě nebylo. 
předávaného sdělení či toho, co se povídá. Je považována za takovou informaci, která ještě nebyla potvrzena ani popřena z oficiálních zdrojů [Kapferer 1992: 19], za formu hledání informací v situaci, kdy oficiální informace nejsou k dispozici, za formu komunikace zkonstruovanou kolem neautorizované informace [Rosnow - Fine 1976: 11] či improvizovanou informaci plynoucí z kolektivní diskuze, výsledek společného intelektuálního úsilí společenské skupiny dospět k uspokojivému výkladu událostí [Shibutani 1966: 17]. Jak se ale fama ve smyslu hodnotného a natolik vlivného mínění stala fámou v dnešním slova smyslu? A proč a jak ztratila pověst té antické a středověké famy, která hrála tak významnou roli ve společenském životě? To jsou otázky, na které se pokusí odpovědět tento příspěvek, kladoucí si za cíl popsat a objasnit vztah mínění a fámy od antiky k renesanci, nebot právě $\mathrm{v}$ této době moc famy upadá a stává se $\mathrm{z}$ ní $\mathrm{v}$ očích veřejnosti neobjektivní a nehodnotné mínění, které je převáženo pojmem opinio.

\section{Etymologie famy}

K př́buzným pojmům famy, která jsou odvozena od téhož základu - fari -, patří například fabula či fando [Bettini 2006: 200]. Spojitost můžeme hledat i v souvislosti se slovem $m y$ thos ${ }^{2}$, nebot Rímané tento výraz s fabulou, která byla vnímána jako nespolehlivá informace, které se nemá věrit, slučovali [srov. Bettini 2006]. Livius definoval fabulae jako historky, kterým by historik za žádných okolností neměl věřit a Cicero pak ve své rétorické teorii rozlišoval naraci na tři části - fabulu, historii a argumentaci, přičemž fabula je podle něj něco, co neobsahuje ani pravdu, ani možnost pravděpodobnosti. ${ }^{3}$ Druhé ze slov - fando - vyjadřovalo obecně rozšířené řeči, pověsti, klepy, šeptandu a vše, co se povídá [Pease 1955: 414]. Jenže právě v kultuře, která byla převážně orální, nutně přicházejí do kontrastu veškeré významy, které všechna zmíněná slova měla, tedy jak objektivní informace, tak fámy či klevety. Sociální dimenze fari, tedy kolování jakékoliv informace, s sebou přináší nutnost brát v úvahu její další odvozeninu, tedy výraz fama . Fama měla dalekosáhlou moc a vliv na každodenní sociální život, byla schopna vyjadřovat souhlas občanů ohledně určitého tématu, veřejnou verzi ohledně určité části informace.

Fama je výraz, jehož kořeny mají široké sémantické pole, zahrnující značnou diverzitu v rozličných významech a užití. Slovo samo o sobě můžeme nalézt převážně v latině nebo latinsky psaných textech, ale i jiné literatury mají svůj vlastní termín. Etymologie latinské

2 Slovo mythos v podání starých Řeků původně neoznačovalo mýtus v dnešním slova smyslu, tj. imaginární vyprávění či historku, která nemá být brána vážně, nýbrž spolehlivý zdroj, určitý druh promluvy. O její spolehlivosti začal pochybovat až Thúkydidés či Hérodotos. Samotný Thúkydidés se při psaní Dějin peloponéské války potýkal s problematikou fémé a mýtu, nebot’ většinou nemohl najít přímé svědky, kteří by mu pomohli v kolujících historkách zachytit jádro faktu. Stejně jako mýtus tak i fémé za sebou zanechává různé stopy v epice, poezii, ódách, dramatických hrách nebo i architektuře, ale stále jsou to stopy historie, která právě je. Historik tak naráží na problém, jak číst a uchopit veškeré události, nebot fémé vyžaduje interpretaci ještě před tím, než se může stát písemných zachycením ústního sdělení. I podle Neubauera [1999] kulturní koncept fémé stojí blízko významu mýtu a sám autor pojem fémé vidí jako pevně spojený s primordiálním počátkem mýtu. Spojitost s mýtem a fémé spatřuje např. u Platóna, u něhož fémé ustanovuje něco jako kolektivní vědomí.

3 Na Ciceronovo rozlišení fabuly a historie později navázal Isidor ze Sevilly, čímž přenesl historii jako výraz pro to, co se skutečně stalo, do středověkého myšlení.

4 Bezpochyby stejný termín existoval i v řecké kultuře, v níž lze nalézt výrazy fémé, fésis, fátis (odvozené pravděpodobně z fémi, tj. řecky mluvím). Další řecké termíny jmenuje Yavetz [1974] - dóxa, ónoma, endoxía, endokíméois a áxíoma, Neubauer [1999] nadto uvádí i termín baxis. Řekové často užívali pro vyjádření mínění personifikaci; tímto se můžeme setkat ještě s pojmem ossa, který původně přestavoval mýtickou bohyni. 
famy má klasické předky a hluboké indoevropské kořeny. Podle historické lingvistiky může být fama odvozena od indoevropského kořene bhá, konkrétně od slova bhanati, což v sanskrtu znamená mluvím, (tj. latinsky fari), zvláště ve smyslu veřejné promluvy.

\section{Sémantická různorodost famy v římském světě}

Užití i vnímání výrazu fama má souvislost s pojmem existimatio, které se používalo jako synonymum pro dobré jméno, vážnost či reputaci, nejčastěji se objevovalo v oblasti politiky, nebở existovalo značné sepětí famy s politickou mocí a s obratností slova. Pojem samotný sloužil jako jakési zastřešující slovo pro několik rozrůzněných funkcí, a navíc se pojmy označující veškeré druhy informací značně mísily. Lze se domnívat, že fama, existimatio či rumor a jim významově podobné výrazy vycházejí z politických pletich v antickém Ř́mě, nebot šíření fám v dnešním slova smyslu bylo v římské republice doslova „národním sportem“ [Yavetz 1974: 45]. Z hlediska zkoumání mínění je problematické zvláště to, že v nejstarších pramenech pojem mínění (opinio) nefiguruje, lze ovšem předpokládat, že tento pojem lze nahradit pojmy consensus humanum, sensus hominum nebo fama, s nimiž operoval Cicero. Pojem existimatio i fama ve smyslu „veřejného mínění používá Cicero, Tacitus, Livius i Julius Caesar. Taktéž se existimatio objevuje ve smyslu reputace (častěji existimatio bona ve smyslu dobré reputace), s takto pojatým pojmem pracuje Cicero nebo Quintilianus.

Existimatio, honor, fama vyjadřovaly něčí reputaci. Diskuze o etymologii významu existimatia jako sociálně signifikantního hodnocení dobrého nebo špatného jednání či chování nasvědčuje, že tento termín stojí blízko Goffmanově výrazu fasáda. Oba koncepty, famy i existimatia, vedou k nahlížení nejenom římských politiků v termínu Goffmanovy seberegulace individuí, kteří si musí nacvičovat a udržovat vlastní přijatelnou fasádu. Původně totiž slovo existimare znamenalo akt ocenění jedince podle sociálních standardů. Thomas Habinek [1998: 46] vysvětluje existimatio jako něco, co zahrnuje ocenění podle standardu a možnosti konverze $\mathrm{z}$ jednoho systému hodnot do druhého. Pojem existimatio podle Habineka pramení z pojmu exemplus aestimare. Aestimare (synonymum existimatia) v římském právu znamenalo oceňovat, hodnotit a osobě, která se cítila uražená na cti, příslušela možnost aestimatorii, tedy jakési žaloby, která se měřila peněžitou pokutou [Kincl-Urfus 1990: 329]. Ř́mský ideál existimatia může ilustrovat, jak byla potupa či ostuda definována římskou kulturou, tedy že svým významem odpovídala stavu neporušené důstojnosti prokázané právem a zvyky.

Abel Greenidge [1894] vysvětluje existimatio jako veřejnou čest, která je spojena s politickou a právní oblastí, ale přiznává, že by bylo třeba najít vhodnější termín. Nadto uvádí, že existimatio je něco, co pozdější právní oblast nazývala statusem. Je také zřejmé, že existimatio je něco, co jedinec nemůže ovlivnit, může jím však být ovlivněn, aniž by byl zahrnut do procesu jeho vytváření. Zneuctěním existimatia vzniká infamia (existimatio a infamii dává do protikladu), tedy zahanbení, z čehož je vidět, že existimatio bylo pojímáno jako čest, reputace. Pro hanbu a její ekvivalenty uvádí taktéž termíny famae damnum či detrimentum fame [Greenidge 1894: 4].

Fama předurčovala to, jak se soud bude k obviněnému chovat, jak s ním bude zacházet a rovněž ho ovlivňovala. Jakmile byl jedinec v římském právu označen jako infames (se špatnou pověstí) nebo famosus (hanebný, ostudný), byla mu odepřena legální práva 
a privilegia, která měli jiní římští občané. Catharine Edwards [1993] píše, že lidé, kteří byli takto označeni, se pohybovali zejména kolem gladiátorů, prostitutek a jinak obviněných kriminálníků, anebo jimi přímo byli, měli limitovaná práva a neměli stejnou právní ochranu jako jiní občané, byli bez famy, bez reputace, bez cti. Dále to byli i herci, pantomimové, někteří muzikanti a kuplíri. V Ř́mě tak fama neovlivňovala jen veřejnou reputaci, ale také předurčovala sociální a právní status.

Infamia byl právní termín pro ztrátu veřejné, civilní cti, infamis byli lidé, kteří ztratili svá práva. Infamia byla považována za morální pokárání vyslovené kompetentní autoritou jednotlivým členům komunity, jako výsledek určitých činů, které spáchali, či určitých aspektů života, který vedli. Toto pokárání zahrnovalo diskvalifikaci určitých práv ve veřejné i právní sféře. Člověk mohl být usvědčený na základě obecného mínění ještě předtím, než byl jednoznačně a expresivně obviněn soudem a soudci mohli shledat těžkým zprostit viny člověka odsouzeného skrze veřejné svědectví, existimatio omnium ${ }^{5}$ či publicum testimonium 6 .

Greenidge [1894: 19] se věnuje pojetí existimatia u Cicerona, který používá pojmy fama a existimatio shodně, jako synonyma, což míní i Zvi Yavetz [1974], oba se také shodují v tom, že význam těchto slov byl blízký dnešními termínu „veřejné mínění. Nicméně Habinek [1998] mezi těmito pojmy vidí značné rozdíly - fama má podle něho co do činění s tím, co druzí říkají o konkrétní osobě, ale existimatio spíše znamená to, jak druzí soudí jedince $\mathrm{z}$ hlediska sociálních standardů. Habinek navíc polemizuje s Yavetzem ohledně konceptu famy a existimatia, je toho názoru, že oba koncepty pocházejí z ranější doby s tím, že fama byla to, co lidé rríkají, tedy jejich mínění, a existimatio bylo jejich ocenění.

Podle Yavetze [1974: 47] lze pojem existimatio zaměnit za pojem fama. Mimo jiné v této době existují taktéž pojmy fama populi, fama nominis Romani, př́íladů pojmu fama existuje mnoho [Yavetz 1974: 36, 47; Pina Polo 2010: 75]. Yavetz tvrdí, že není vhodné pojem fama vnímat jako a priori založený na fámě či zvěstech. Nicméně pojmy existimatio a fama je těžké jasně vyložit, nebot' se v pramenech objevují jak ve smyslu fámy, lži, nepravdy, tak i ve smyslu mínění, jak veřejného, tak i osobního, ve smyslu dobrého jména či reputace konkrétního jedince. Fama a existimatio jsou tedy bud' zaměnitelné pojmy, nebo se mezi nimi rozlišuje, tehdy je fama vnímána jako více vágní pojem, založený na fámách a zvěstech, zatímco existimatio znamená dobré jméno či reputaci mezi určitou skupinou.

V Římě mělo obecné mínění značný význam. Ř́mský politický diskurz zahrnoval několik termínů, které byly používány k označení současného konceptu „veřejného mínění, zejména termíny fama a existimatio, ale také opinio a consensus hominum. Mít pozitivní famu nebo existimatio záviselo dosti úzce na tom mít důstojnost a ztělesňovat autoritu, což bylo vyžadováno držením prominentních pozic v římské politice a většinou i přístupem do vyšších či dokonce nejvyšších pozic. Existimatio bylo míněno jako občanská čest, tedy předpoklad právní způsobilosti, naopak infamia znamenala právní bezectnost. Soudobé vnímání „veřejného míněni““ nemůže být dáváno do souvislosti pouze s aristokracií, nýbrž i s městským plebsem, který měl stejně tak moc ho ovlivňovat.

5 Existimatio omnium je použito např́klad v Řečech proti Verrovi (II.3) nebo v Rétorice pro Herrenia (IV.14) [Yavetz 1974: 47].

6 Publicum testimonium použil Quintilián v Základech rétoriky (V.III). Zajímavé je, že Václav Bahník přeložil výraz publicum adjektivem veřejné. Není to však žádná výjimka, nebot např. Cicero je považován za prvního, kdo použil soudobý termín veřejné mínění, tedy publicam opinionem [Noelle-Neumann 1993: 227]. 
Formování obecně přijímaného mínění o jedinci ovlivňovalo několik faktorů a šírilo se jak skrze psaná média, tak i ústním přenosem. Psané formy propagandy se rozmáhaly zvláště mezi elitou, což ovlivňovalo názory uvnitř této skupiny. Názory v psané formě však mezi plebs spíše nepronikly, nebot tito občané většinou neuměli číst, ale ani k nim neměli přístup [Pina Polo 2010: 76]. K šíření některých myšlenek po městě a k tvoření obecného mínění sloužily i fámy. Ř́mští politici moc dobře věděli, jak pro ně šíření fám může být důležité, proto se snažili být vždy v obraze, třebaže byli i mimo město. Cicero poukazoval na slabost kandidátů proti fámám (rumores, fabula ficta, sermones) a dodával, že existence fám značně zkresluje obecné mínění. K šíření fám se vyjadřoval i samotný Caesar, nebot’ o něm jich v samotném v Rímě kolovalo několik. Sám zastával názor, že fámy rozšiřují susurratores (našeptávači), jimž například přičítá fámy o smrti Cicerona. Susurratores či subrostrani (totožný, ale vzácně používaný termín) byli lidé zahálčiví a také lidé s nízkým sociálním statusem, kteří trávili své dny lelkováním kolem Fóra, největšího informačního uzlu celého Říma. Fámy mohly spontánně vznikat tak, že susurratores odposlechli to, co vystupující rríkali, přeformulovali si to podle svého uvážení, a především svých zájmů; následně pak takto zkreslenou informaci vydávali za všeobecný názor. Sociální sít těchto lidí poskytovala četné kontakty s jinými členy městského plebsu, čímž se zvyšovala efektivita šíření, a to zvláště proto, že se komunikace nešírila skrze metaforu řetězu, ale sítě.

V pohledu římských politiků vznikaly fámy především v prostředí plebsu, který si jejich šířením ventiloval deprivaci svých práv. Vzhledem k tomu, že i tito občani měli sílu ovlivňovat famu kandidátů - tedy jejich pověst, reputaci, mínění o nich samých, vznikala obava elity ze šíření jejich mínění. Šiřitelé obávaného mínění byli označováni jako circulatores - šiřitelé zpráv, mající podobnou funkci jako zmínění susurratores. Pocházeli $\mathrm{z}$ malých skupinek osob (circuli) a scházeli se, aby rozprávěli o různých záležitostech. Šlo o skupinky konverzujících lidí všech vrstev, profesních skupin, ale do popředí pozornosti se dostávaly pouze circuli plebsu, které byly dávány do souvislosti i s formováním nebezpečných fám [O’Neill 2003: 145]. Členové senátu, rétoři i politici považovali circuli za něco nebezpečného, a proto je i častokráte podrobovali kritice - např́klad Cicero mluví v souvislosti s promluvami lidu o plebeius sermo ${ }^{7}$, Livius pak o circulus sermo ${ }^{8}$ a plebis rumo$r e s^{9}$, přičemž tyto termíny jsou dávány do přímého kontrastu se seriózními promluvami senátorů. Z toho lze usuzovat, že o informacích, které šírily circuli mezi senátory či vyšší třídou valné mínění nebylo.

\section{Přechod ke středověkému právu}

Existimatio zůstávalo i nadále důležitou právní i sociální kategorií, častěji se však namísto výrazu existimatio používal výlučně pojem fama, například stejně jako v římském právu v existenci pojmu bona existimatio, existovalo v tom středověkém bona

\footnotetext{
7 Plebeius sermo (napr. Fam. VIII.21), podobně pak sermo in circulis (De off. I.132).

8 V českém překladu jako zavádět řeči mezi lidem (III.17). Výraz sermo sloužil stejně jako rumor k označení klevet a fám. Sermones ve smyslu fám používá také Tacitus, který zmiňuje fámy o Germanikově smrti, kterou způsobil plebs svým šířením [Potter 1999: 72], hominum sermo bylo častěji spíše myšleno jako běžná řeč.

9 Do češtiny přeloženo Pavlem Kucharským [1976] jako pobuřující řeči mezi lidem (XXVI.26).
} 
fama, opozitem byla mala fama, jejímž ekvivalentem byl více rozšířený pojem infamia ${ }^{10}$. Existimatio v římském právu považuje Greenidge [1984] za totéž, co znamená fama ve středověkém.

Stěžejním mezníkem ve středověkém právu bylo přijetí Justiniánova kodexu (Corpus iuris civilis), základní modifikace římského práva, $v$ jehož době fama znamenala reputaci a stala se tak primárním právním pojmem. Nicméně znamenala i něco jiného - obecné vědění, obecné znalosti o určitých událostech, jevech či právních situacích, které byly stabilnější než fámy a často byly odosobněnější než reputace. Justiniánův projekt kodifikace římského práva započal v roce 528, krátce po jeho dosazení na trůn. Původní idea byla nahradit dřivější kompilace jako Codex Theodosianus (438), ve kterém fama byla rovna pojmu existimatio. V Digestě (3.2.24, 24.1.3 aj.), jedné z částí Justiniánova kodexu, je existimatio a fama použito podobně, tj. jako názor a mínění určité osoby. Zde konkrétně je použito aestimatio ve smyslu ohodnocení, ocenění (např. 2.4.2, 3.23.1) [srov. Justiniánské instituce 2010]. Taktéž se zde dozvídáme o pojmu famosus, který je ekvivalentem infamis. Infamia figuruje v Justiniánově kodexu ve smyslu bezectnosti, nečestnosti.

$\mathrm{Na}$ Západě, ve Francii a Španělsku, nebyla Justiniánova legislativa rozšířena. Hlavní dokument zachovávající římskou tradici (konkrétněji Codex Theodosianus) byl soubor Lex Romana Visigothorum. Pozdější Vizigótský kód obsahoval značná ustanovení ohledně infámie. První pravidlo zakazovalo určitým lidem svědčit, byli to vrazi, zloději, vězni a ti, co měli něco do činění s čaroději. Za infames byli označováni i ti, kteří podali falešné svědectví. Vizigótský kód obsahuje mnoho ustanovení, která odkazují k infamii a k tomu, jak se člověk mohl stát infamis. Kód přímo nespecifikovává definici infamie, ale několik pasáží srovnává infamii s nezpůsobilostí svědčit [The Visigothic Code]. Ve 13. století za vlády Alfonsa X. byl Vizigótský kód nahrazen Siete Partidas, právním kódem složeným ze sedmi částí. Sedmá část se systematicky zabývá právní infamií ve španělském právu, konkrétněji ztrátou privilegií a různých práv v souvislosti s pověstí jedince. Na rozdíl od Vizigotského kódu však Alfonsova legislativa přesně definuje famu, tedy reputaci, jako mravní stav člověka, který žije podle práva a dobrých zvyků a mravů [Bowman 2003]. Siete Partidas definoval pojmy opatrně, rozlišoval infamii i špatnou reputaci (mala fama). Stejně tak Aragonský kód Vidal mayo ze 13. století uvažuje bona famu i mala famu. Stejně jako mnoho jiných středověkých kódů diskutuje použití famy jako formy důkazu, většinou je však znát, že rozdíl mezi infamií a mala famou bylo v praxi těžké zachovávat. Mala fama, rovněž také infamia či infamia facti, tedy urážka na cti, špatná pověst či bezectnost, způsobovala jak ztrátu cti, tak i ztrátu důvěryhodnosti jedincova svědectví, který tak byl vyjmut z ochrany soudu a mohl být vystaven mučení.

Pro studium infamie, bezectnosti či hanebnosti, je nezbytné podívat se na její protiklad - dobrou pověst čili existimatio, famu. Právníci 12. století často ve svých sumách používali pojem existimatio, který přejímali od římského právníka Kallistrata, objevuje se např. v Summě Trecensis (1170), kde autor říká, že existimatio, neboli reputace, je přirozeností

10 Existoval však i další termín, ačkoliv méně často používaný, ignominia (doslova beze jména). Tento termín používá např́iklad Isidor ze Sevilly. Ten dále ve svých Etymologiích uvádí, že infamis znamená hanbu či ztrátu dobré pověsti. Slovo fama je dle něj odvozeno od slova fari právě proto, že „se za pomoci řeči a sluchu plazivě rozrůstá jako révové úponky“ (V.26). Isidor rovněž upozorňoval na nebezpečí bezmezného spoléhání se na famu. Uvádí, že „není na místě považovat pověst za něco jistého, protože je často lživá a mnohé přidává nebo překrucuje pravdu; žije tak dlouho, dokud se pravda nedoloží důkazy. Jakmile se pravda prokáže, pověst ustoupí a od toho okamžiku už se nazývá skutečností, nikoli pověstí“ (V.27). 
člověka. Další kanonické zmínky o infamii byly formulovány Rufinem (1160) s úzkou spojitostí na římské kategorie a termíny. Představa toho, že existimatio je něco přirozeného, byla rozvinuta plně až Placentinem, jehož pojímání se později objevilo v Summa Codicis Azzone, systematickém výkladu římského práva, jehož autorem je Irnerius Guarnerius. Placentinus opakuje definici existimatia výše zmíněnou, k čemuž ještě přidává další totožné pojmy - fama a opinio. Existimatio je odvozeno př́mo z přirozené důstojnosti, v jistém smyslu je i jeho synonymem. Rufinus limitoval kvalitu existimatia pro svobodného člověka, což se objevilo i v Summě Coloniensis (1169), kde se existimatio také popisuje, nicméně zde je již namísto něj použit termín fama. V Summě Coloniensis je existimatio vnímáno jako dar přírody. Existimatio a fama se pak objevují i v dalších právních sumách ${ }^{11} 12$. století, veskrze však popisovaly existimatio, famu jako něco přirozeného, dar od přírody či společnosti, jako něco, co si člověk zaslouží jako člen společnosti, např́klad v Summě Sicarda z Cremony (1180) autor spojuje existimatio s morální ctí, v Gratiánově dekretu ${ }^{12}$ (1140), prvním systematickém zpracování civilního práva, se taktéž objevoval pojem fama ve zmíněném smyslu [Livingston 1962].

Naproti tomu infamia byla definována jako totální nebo částečná ztráta veřejné úcty či civilních práv. Infamia byla iuris a canonica, přičemž ta vycházela $\mathrm{z}$ aktu exkomunikace a znamenala ztrátu famy, a její výsledek se odvozoval od každého jednotlivého deliktu. Rovněž existoval pojem infamia facti, jinak zvaný i mala fama, ta mohla vyrůstat spontánně z fám. Znamenala fámy nebo podezření na kriminální chování. Rufinus ve své Summě uvádí další termín mala famy, tj. inistro rumore, sinistra fama [Livingston 1962: 89], tedy hrozivá, zlověstná fáma.

Infamia iuris i infamia facti měly dalekosáhlé právní důsledky, přičemž horší byly u infamie iuris. Ta vycházela z definice právních interpretací Justiniánových norem a byla více všeobecná, naopak infamia facti byla způsobena výlučně komunitou, působila jako sociální stigma, které ovlivňovalo každého jedince v okolí, o němž se v komunitě šířily zvěsti, že spáchal nějaký zločin, bylo to jakési sociální pohanění, které pošpinilo ty, kteří se vyhýbali rozsudku v potupném kriminálním procesu; bylo to také označení pro sociální diskreditaci těch, kteří byli veřejně obvinění, rovněž se tak vyjadřovalo ponížení, které viník akceptoval jako část uspokojení oběti v rámci vyjednávání, dále to znamenalo nesmazatelnou stopu v životě jedince, který se narodil nelegitimně, a v neposlední řadě byli takto vnímáni lidé, kteři se zabývali určitou profesí, kvưli níž byli pokládáni za bezectné a nečestné [Bettoni 2010].

Ztráta famy měla dalekosáhlejší důsledky v kanonickém právu než v civilním, čehož si jako první explicitně povšiml Joannes z Faenza [Livingston 1962: 96]. Fama může být narušena či poškozena nějakým hrozivým činem, ačkoliv stupeň poškození variuje se závažností hříchu. Joannes z Faenza definoval infamii facti jako dábelskou fámu samu

11 Summa označovala samostatnou cvičebnici církevního práva zpracovanou z látky Gratianova díla bez uvedení jeho prrímého textu, ten byl jen citován v poznámkách [Michal 1967: 43].

12 Gratianovo dílo se stalo předmětem studia mnoha církevních i světských právníků, kteří se věnovali výkladu díla a stali se učiteli samostatného církevního práva, byli označováni jako dekretisté. Gratianovo dílo bylo nejenom na církevním právním poli vážené, stalo se základem samostatné právní vědy. Následovníci Gratiana byli Rufinus, Joannes z Faenza, Sicardus z Cremony nebo Joannes Teutonicus. Kromě dekretistů měly význam i práce tzv. glosátorů, kteří pěstovali právní vědu, mezi nimiž nalezneme významné učitele práva Placentina a Aza. Na ně pak v pozdějším století navazují glosátoři chtějící přizpůsobit Corpus iuris civilis praktickým potřebám, jsou to Bartolo de Sassoferrato či jeho žák Baldus de Ubaldi. Jak dekretisté, tak glosátoři zahrnovali kategorii infamie facti do práva a přisuzovali jí právní důsledky. 
o sobě, jako př́ípad ztráty reputace ${ }^{13}$. Rufinus, italský kanonický právník 12. století, definoval infamii jako zlověstnou fámu. Joannes Teutonicus svědčil pro růst důležitosti výslechu jako druhu pro rozhodování o důvěryhodnosti mala famy před očistou.

Předtím než jakákoliv osoba mohla požadovat očištění soudem, musel k tomu být důvod. Pokud osoba podezřelá ze spáchání činu vznesla námitku, bylo protiprávní pro soud oficiálně jednat bez zjištění či založení na legitimním obrazu famy publicy [Helmholz 2001: 96]. Soudcům bylo zakázáno neověřeně postupovat v připisování očištění, první kontrolou bylo svědectví jakékoliv osoby předvolané před veřejným soudem, standardem bylo, že byl zapotřebí důvěryhodný hlas několika sousedů. Jakékoli svědectví při očištění však nemohl dosvědčit jedinec, který byl objektem veřejných fám či byl infamis.

\section{Fama jako mechanismus kolektivního hodnocení}

Komunita byla ve středověku stěžejním elementem, individualita jedince jí byla ovlivňována a on byl tak silně spjat se skupinou, do které patřil. Jedinec byl důležitý jedině tehdy, pokud patřil k nějaké komunitě, at už k městské, klášterní, cechovní nebo rodinné a jeho život měl význam, zejména pokud byl zapojen či byl součástí komunitního života. Ve středověku existovalo několik autonomních skupin, které koexistovaly a regulovaly samy sebe. Neexistoval nejvyšší zákonodárce, právo přicházelo zdola. Souhrny norem a urovnávání právních konfliktů bylo od 12. století zvláště na právnících, kteří byli srdcem právního systému a jen oni mohli garantovat jeho funkčnost. Právní oblast je sféra, která zahrnuje komunitu, jež chrání své členy, ručí za ně a přijímá strategie, jak urovnávat konflikty, či za jedince vyjednávat.

Fama, termín používaný zvláště v latinsky mluvících kulturách, znamenala obecné mínění, běžné řeči, čest i pověst, stejně jako slávu, oboje ve smyslu dobrém i špatném. Termín fama, vypůjčený z procesního římského práva, figuruje jako důležitý element taktéž ve středověkém soudnictví. Byla to tak důležitá věc, že se soudci i právníci svědka ptali, přestože to nebyla jejich povinnost, co rozumí pod pojmem fama a jaká je fama obžalovaného. Svědci většinou odpovídali v tom smyslu, že fama jsou věci, které lidé ř́kají, hlas veřejnosti a slávy, to, co se běžně traduje mezi lidmi o některé osobě. Většinou ji tvořilo několik málo lidí, někdy však celá skupina, pak se užíval pojem magna fama. Běžná komunikace lidí tak vytvářela famu, která hrála stěžejní roli v soudní síni. Svědek ani nemusel mít př́imou zkušenost s obžalovaným, stačilo jen, aby někdy něco od někoho zaslechl. Fama tak byla souhrnným názvem pro jakékoliv veřejné mluvení, které soustavně ustanovuje čest, pověst nebo status. V tomto smyslu může být i politická, nebot slouží k definování konkurentů v oblasti veřejné, což může být předpokladem pro získání veřejné funkce. Fama je tedy něco, co je dáno druhými lidmi, kteří ji ustanovují svým neustálým hodnocením a sdílením onoho hodnocení s ostatními. Co bylo veřejností akceptováno jako pravdivé, bylo takto akceptováno i v právu. Aspekt famy v souvislosti s osobní reputací musel mít obrovský důsledek na schopnost lidí žít $\mathrm{v}$ komunitě a v souladu s komunitou. Mnoho soudních případů v tomto kontextu vypadalo tak, že měla větší šanci na výhru u soudu osoba s lepší famou, i když delikt skutečně spáchala.

Fama publica nebyla nevypočitatelný pojem. Koncept středověké famy vylučoval fámu v dnešním slova - fáma byla označením pro řeč v soukromí mezi několika málo lidmi, ale

13 Michal [1967] upozorňuje, že summa Joannese z Faenza je plagiátem opsaným z Rufina. 
fama byla kolektivním svědectvím, kolektivním hlasem a hodnocením. $Z$ dnešního pohledu by se ale dala publica fama s fámou ve své odborné definici připodobnit. Fama publica bylo něco, co každý ví, co bylo sociálně akceptováno jako spolehlivé [Wickham 2003: 17].

Ve 12. století se fama používala jako obecné vědění, poměrně často tedy jako právní termín. Po roce 1250 se stala součástí právní teorie v každodenní praxi, především skrze důkazní řízení. Fama, stále častěji však fama publica, někdy i vulgaris et frequences fama (běžná a častá pověst), communis fama (obecná fama) nebo consentiens fama (souhlasná fama), byla formou vědění. Do protikladu byla dávána s termínem per visum (přímé svědectví), které bylo více spolehlivé a bylo odlišováno od per auditum (klepy, pomluvy), které nebylo spolehlivé za žádných okolností.

Na počátku 13. století se v soudních procesech začal objevovat pojem inquisitio, který nahradil dříve používaný pojem accusatio známý z rrímského práva. Kvůli tomuto posunu byly soudy ustanovovány na publica fama et vox, na základě mínění komunity o obžalovaném. V italských dokumentech ze 13. století [srov. Mucciarelli 2013] lze nalézt význam fama ve smyslu reputace i slávy nebo obecného mínění. $V$ době procesu zesilování veřejného systému práva a soudnictví nabírala fama na významné a důležité roli. Byl to mocný rétorický nástroj, jakýsi symbol shody veřejnosti. Italský právník Tommaso da Piperata (1253-1282), navazující na své předchůdce, kteří započali zřejmě od roku 1186, kdy je znám první text takové druhu, uvažovat o vlivu a akceptování famy jiným než dosavadním způsobem, ve svém spise Tractatus de fama vysvětloval famu jako obecné mínění. Důležitým faktem, který se v této době objevil, bylo převzetí pojmu fama jako spouštěče soudních přelíčení [Mucciarelli 2013: 201]. Fama v 13. a 14. století nabírá přední pozici v debatách, $v$ reflexích právníků, kteří debatují o jejím charakteru, validitě a limitech její reliability a skutečné hodnoty pro obžalobu.

Další italský soudce Bartolo da Sassoferrato (1314-1357) rozlišoval dva druhy famy první je fama jedince, založená a vázaná na jeho morální kvality, druhá fama je propojena se specifickými skutky, činy či chováním [Mucciarelli 2003: 205]. Fama musí být demonstrována významem svědkovy dobré víry a reputace a byla považována za prokázanou, když ji většina lidí v rámci komunity potvrdila. Dále popisoval famu jako běžné obecné mínění založené na určitém faktu a požadoval, aby svědci v soudním procesu deklarovali, že obecné mínění bylo vyjádřeno majoritou a veřejně, tedy jakoby skrze vox et fama, spojení známé i v inkvizičních výsleších a v jiných právních dokumentech, často jako součást svědectví i konečných rozsudků soudů. Osobnost Bartola je velmi zajímavá, nebot právě on vyzdvihoval fakt, že k poznání obecného mínění (communis opinio) je potřeba dobře znát veřejnost, tedy, že obecné mínění je potřeba poznávat skrze veřejnost a její hlas, vox populi. Názory Bartola následoval další významný právník nyní již 14. století Baldus de Ubaldi, právě on se nejvíce zasloužil o ustanovení communis opinio [Bettoni 2010]. Ubaldi poukazoval na to, že rovněž svědectví bezectných lidí může dát platný podnět i k započetí obecného výslechu.

Důkazní ŕízení se zakládalo na centrální roli sousedské famy [Vallerani 2012: 52]. Soudce se většinou nespokojil jen s př́mým svědectvím, ale zajímaly ho i určité znaky nepř́ímých důkazů, tedy to, co se povídá - klepy, fámy a všechno, co se kde šušká. Mezi různými druhy důkazů, které byly v průběhu soudu brány v potaz, měla fama centrální roli se silnou důkazní hodnotou, bylo to něco, co každý ví, co je společensky i právně přijímáno jako spolehlivé. Fama jako kolektivní ohodnocení obžalované osoby byla schopna př́mo 
ovlivnit model či způsob vyšetřování. Vyšetřování pojímané jako hnací síla bylo schopno zničit jedince jako takového, což poukazuje na vztah mezi občanstvím a soudem, mezi individuálním chováním a integrací jedince do komunity. Fama byla jak odsuzující, tak žalující prvek, mohla determinovat to, jaký druh či kolik soudů musel onen jedinec podstoupit. Pokud disponoval jedinec bona famou, mohl mu být uložen trest ordálem, který středověké právo považovalo za důležitý pro odhalení viny v právním systému středověké Evropy a sloužilo jako hlas boží, vox dei.

Ve středověkém soudnictví se klade velký důraz na famu, na její funkci, která se ve svém mnohočetném významu stala primárním motorem, hnací silou soudů, takže byla základním nástrojem důkazního řízení založeném zejména na nepř́ímých důkazech [Vallerani 2012: 47]. Soudní jednání vycházelo ze svědectví jedince, který referoval o obžalovaného famě, avšak svědectví se mohlo zvrátit ve lhaní, či být úplně vyvráceno jiným svědectvím. Nicméně soudce měl takové pravomoci, že mohl vyslechnout svědka bez křížového výslechu a sám se rozhodnout, zda má odložit či pokračovat v procesu objasňování jedincova provinění se a odsouzením k bezectnosti.

Fama ve smyslu reputace byla tvořena sítí vztahů, které předurčovaly postavení jedince v sociální integraci a ve stupni jeho přijetí, byla to důležitá proměnná v životě komunity, zvláště v době krizí a konfliktů. Fama byla produktem rozličných typů sociální organizace, které předpokládaly modely chování ve společnosti a v zákonném mechanismu, který přiděloval vedoucí pozice. S tímto dvojitým míněním slávy a reputace byla fama vysoce formalizovaným konceptem, který byl striktně ustanoven a korespondoval s veřejným chováním, ekonomickým statusem a sociálními vztahy, v podstatě tak představoval produkt vztahů moci a solidarity. Je zde vidět značný rozpor mezi famou jako dobrou pověstí a famou jako špatnou reputací. Fama hrála velkou roli v předurčování statusu. Lidé se spoléhali na slova či názory druhých i jen pro jejich status. A zde vidíme signifikantní roli famy ve středověkém právu - jedincova fama byla veskrze úplně mimo vliv samotného jedince, nebyla v jeho vlastních rukách, ale rukách ostatních.

Popis událostí skrze právní terminologii je to, co vytváří právní skutečnost. Clifford Geertz [1983: 172-173] v tomto kontextu popisuje, že dochází k jakési skeletonizaci skutečnosti, tedy k tomu, že skutečnost je popisována tak, aby odpovídala kategoriím, které předpokládají právní řád. Geertz ukazuje, že právo je tvořeno především věděním místních, je to princip, který se váže k určitému místu, je to stavební kámen sociálního života, sousedství a komunity, ve které žijeme.

Fama publica je konstituována mluvením o různých tématech, jinými slovy, stojí na klevetách, pomluvách a fámách [Wickham 1998: 5]. Byla však tvořena zejména muži, zatímco ženy tvořily spíše famu privatu. Wickham tak rozlišuje mezi famou publicou jako právně relevantním termínem, který legitimizovaly i tvořily skupinky mužů, a které byly pokládány za relevantní a důvěryhodné pro veřejnost a právní sféru, a mezi famou privatou $^{14}$, která mohla zahrnovat ženské mluvčí, a která byla rozdílně konstruovaná - byla

14 Například Kuehn [2003] takovéto pojímání vidí i v 15. a 16. století v Marseille. Stejně tak de Vivo [2007] ukazuje, že v Benátkách na počátku 17. století byly ženy považovány za klevetící, zatímco muži ne. Slova patřila ženám, činy mužům. To, co Wickham ukazuje již ve 12. století, přetrvává až do počátku 17. století (ovšem v populárních názorech se udržuje dodnes). Tento znatelný rozdíl přetrvávající od středověku ukazuje, že mluvení bylo rozděleno pohlavím, tedy že muži i ženy často používali rozličné řečnické strategie. Je poukazováno také na to, že klevety a fámy, typicky asociované se ženami, byly ovládány muži jako politické nástroje u soudů. 
méně formální, méně hierarchická, o to více zajímavá, avšak nebyla podstatou uznávaného druhu obecného vědění, neměla vliv na obecné mínění ${ }^{15}$ a na obecné znalosti, které byly právně akceptovatelné.

Ilustraci toho, jak vypadala ve středověku fama privata, lze spatřit v německé právní knize ze 13. století - Saském zrcadle (Sachsenspiegel). Latinský překlad se ztratil, takže není známo, zda byl pojem fama v originále obsažen, ale je zřejmé, že právo saské o famě v tehdejším smyslu slova pojednává. Fama tehdy hrála významnou roli v orální kultuře soudních jednání, nicméně byla konstruována a kontrolována zejména muži. Konstruování bona famy a mala famy tak bylo v rukou mužů. Verbální vklad ženy byl těžce zredukovaný, v nejlepším mohl být nepřímo sdělovaný poručníkem, v nejhorším byl ze strany muže vyvrácen, nebot jeho svědectví bylo hodnotnější i než přímé svědectví ženy. Mužský svědek mohl podpořit famu muže obviněného z nějakého činu, nebo ho jeho vlastní přísaha mohla zprostit obvinění. Muži také byli v pozici, kdy mohli očernit každého, zatímco ženy jen sebe samy. Dívky a ženy podle práva musely mít u soudu poručníka, nebot’ samy nemohly svědčit ve věci, o kterém před soudem mluvily. Co se týče pohlaví svědků, tak byly značné rozdíly v právu té které země, stejně jako v obdobích. Wickham [2003: 25] uvádí, že v Toskánsku 12. století bylo nepřijatelné, aby ženy svědčily, stejná situace byla v Německu, naopak ve 14 . století v Marseille nebo v 15. století ve Florencii měly ženy nepochybnou důležitost.

Obecně se v pramenech středověku i raného novověku objevuje mnoho soudních procesů, ve kterých se objevuje tehdy závažný trestný čin - pomluva (diffamia, i zde je vidět základ slova - fama). Klíčovým právním konceptem v procesu pomluvy je fama, lokální sít znalostí. Je pravda, že př́mé svědectví bylo jediným právně přijatelným věděním, ale fama publica k tomu měla blízko, bylo to něco, co každý ví, bylo to sociálně přijímané jako spolehlivé a věrohodné. Jenže i přímé svědectví bylo ovlivněno tím, co se o daném člověku říká, jeho famou. V soudnictví byla fama vždy vázána na konkrétní osobu či událost. Byl to sice abstraktní koncept, ale měl své specifické aplikace. V soudním systému byla fama také využívána zákonnými autoritami k ohodnocení spolehlivosti. O lidech se předpokládalo, že znali famu svých sousedů. Fama je často vnímána jako klíčový aspekt sousedských či komunitních vztahů. Ve středověkém pojetí se fama všeobecně vnímala a používala ve smyslu místních znalostí, ale takových, které byly konstruovány i zkreslovány reputací, klevetami i fámami [srov. Fenster - Smail 2003; Wickham 2003; Vallerani 2012].

15 Ovšem již v pozdním středověku lze doložit strach mužů z klevetění žen, zvláště kvưli jejich zvyšujícímu se oprávnění, které jim umožňovalo potvrzovat, vyvracet a autorizovat jakékoliv informace. Ve skutečnosti kulturní znázorňování klevetících žen sloužilo k odlákávání pozornosti od zvyšující se mužské obavy ze ztráty výlučného konstruování a kontrolování informací. Tímto způsobem mohlo docházet k rozlišování fám v dnešním slova smyslu, které však stále byly tvořeny muži, a klevet, jež tvořily ženy [Botelho 2009]. Avšak nadále to byli zejména muži, kteří kontrolovali či manipulovali s pravdou i s fámou. Klevety a fámy nebyly tvořeny jen ženami, naopak velkou měrou se šířily skrze kněžská kázání v kostele či pastorační úkony [Phillips 2007; Menache 1991]. Redukovat veškeré obecné řeči na čistě ženskou doménu tak přináší opomínání jiných, stejně důležitých cest, kterými byly tyto řeči šířeny. Susan Phillipsová [2007] ve své knize popisuje roli klevet ve středověké anglické kultuře. Definuje klevety jako rozšířené prázdné řeči, tzv. tlachání. Problematizuje předpoklad, že klevety jsou primárně ženskou doménou a poukazuje na to, že důraz na ně se kladl v pastoračních úkonech. Kněží sice své posluchače varovali před klevetěním v kostelech, ale na druhou stranu totéž dělali ve svém kázání. Autorka v podstatě říká, že klevety a pastorační rétorika jsou hluboce protkány [Phillips 2007: 8]. Zpověd’ je sama o sobě klevetou a kleveta se může stát zpovědí, doznáním, přiznáním. Klevetění je přirozenost lidského chování stejně jako mluvení, je nevyvratitelné, nevyhnutelné, nekontrolovatelné a nepředpověditelné. 
V českých zemích byla situace podobná. Z nejcharakterističtějších rysů soudního řízení byly ordály, boží soudy, v 11. a 12. století byly neodlučitelnou součástí práva, a to zhruba do 15. století. Ve středověkém trestním procesu záleželo na tom, zda se obviněný musel očistovat, či zda byl usvědčován. Pokud se očistoval, mohl si pozvat tzv. očistníky, čili svědky, kteří byli v té době důležitým prostředkem pro to, jak se zbavit obvinění a žaloby. Funkce těchto svědků je vyjádřena jejich označením očistníci, nebot vypovídali u soudu ne o tom, co sami viděli či slyšeli, ale o tom, že jsou prostě přesvědčeni, bez udání důvodu, o vině či nevině obviněného a o pravdivosti či nepravdivosti žaloby a toto přesvědčení jsou ochotni stvrdit před osudem př́sahou [Vaněček 1976: 123].

Také v české oblasti se objevuje termín fama. Např́iklad publica vox et fama se objevuje ve zlomku protokolu Fragmenta actorum iudiciariorum o rozepři pražského johanitského kláštera u Panny Marie o jakýsi úrok, zřejmě z roku 1402 před soudem pražského arcibiskupa. ${ }^{16}$ Stejný výraz nalezneme v explicitu titulu Registrum (15. století) či ve Vitae sanctorum (1380-1400), stejně tak termín bona fama nalezneme v českých archivech, a to v díle Sermones zřejmě od Jacobuse de Marchii (?) ze 13.-14./15. století, dále v incipitu Statuta et privilegia Praemonstratensis ordinis (13.-15. století), souborů textů liturgické povahy, zde se mala fama objevuje ve smyslu špatné pověsti některého $\mathrm{z}$ bratří. Bona famu používá též Jan Hus v Recoomendatio magistri Proice omnia ista (15. století).

\section{Diskuze o procesní roli famy: od pravdy k pravděpodobnosti}

Již ve třináctém století probíhala důležitá diskuze o famě a její procesní roli [Shapiro 1991: 119]. Obecná fama byla dostačující k zadržení podezřelého a k iniciování soudního procesu, ale sama o sobě byla postupem času nedostačující k odsouzení či mučení. Pouze přiznání nebo svědectví dvou bezúhonných svědků bylo třeba k plnému či právními důkazu v důležitých kriminálních deliktech. Dostačující a kompletní důkaz v důležitých kriminálních záležitostech nebyl vždy dostupný a možný. Dva dobří svědci nebyli obyčejně přítomni a ani doznání nebylo v dohlednu, proto poté následoval inkviziční proces, který mohl zahrnovat mučení jako prostředek pro získání přiznání.

Teoretikové práva $\mathrm{z}$ univerzity v italské Boloni, kde se od 11. století začaly studovat Justiniánovy zákoníky, které se staly základem pro přijetí ŕímského práva ve středověku, již jmenovaní da Piperata a da Sassoferrato, dále např. Alberto Gandino (1245-1310), byli první, kteři začali o famě publice uvažovat zcela odlišným způsobem. V té době tak rozpoznáváme dva druhy famy - první význam ve smyslu reputace jedince obžalovaného z nějakého činu (užívány i výrazy opinio či status), na druhou stranu to byla fama činu, tedy názory či dohady ohledně důvodů pro spáchání skutku. První fama hrála velkou roli pro orientaci soudce v osobnosti jedince, v tom jak ho má vnímat a jak se pak má rozhodovat.

Fama stále sloužila jako klíčový prvek důkazního řízení, byla prezentována a vnímána jako centrální pro orientaci v soudním systému Evropy pozdního středověku. Zlom nastal u italského právního teoretika Gandiniho [srov. Vallerani 2012], podle něhož fama tvořená pouhými několika svědky není dostatečným důkazem v soudním procesu proti osobě, která nebyla veřejně dotčena, proto rozlišuje famu činu a famu (rovněž zde použit

\footnotetext{
16 Fragmenta actorum iudiciariorum [online]. Dostupné z: <http://www.manuscriptorium.com/apps/main/ index.phprequest=show_tei_digidoc\&virtnum $=30 \&$ client $=\& d d \_l i s t p a g e \_p a g=11 \mathrm{v}>$ [3. ledna 2014].
} 
i pojem opinio) jako obecné mínění o určité osobě. Avšak to, že člověk má dobrou famu, neznamená, že nemůže spáchat zločin, nicméně Gandini toto slučuje - podle něj člověk s dobrou famou nemůže spáchat zločin, dobrá fama je jakási záruka pro nespáchání zločinu. Toto pojetí je v soudním procesu klíčové, protože zločin takové osoby díky famě nemusí být souzen. Da Piperata a Gandini byli současníci, boloňští soudci, oba pracovali v soudnictví s pojmem fama, považovali ho za důležitý, avšak vedli spor o to, zda je možné mučit člověka na pouhém základu famy. Piperata tvrdil, že spíše ne, Gandini naopak, ačkoli tvrdil, že fama může vést $\mathrm{k}$ mučení, ale ne k definitivnímu odsouzení a vnímá ji jako extrémní formu nápravy aplikovanou v př́padech zvláště špatné pověsti či obvinění ze závažných činů. Da Piperata sledoval představu, že obviněný by měl být odsouzen pouze na základě nezpochybnitelných výpovědí či okolností činu, ale jeho pohled nebyl příliš následován. Zdůrazňoval, že o jedinci mohou svědčit jen ti, kteří ho znají osobně, ne pouze z doslechu. Tommaso da Piperata definoval famu jako to, čemu lidé obecně věří a předávají to dále [Evans 2002: 127]. Podle Gandiniho je fama status nezpochybnitelné důstojnosti, projevený zvyky a právem (tuto definici přebírá od římského právníka Kallistrata) [Bowman 2003: 103], ale rovněž ji vnímá jako posuzování jedince jako člověka [Vallerani 2012: 106].

I ve francouzské právní oblasti nalezneme posun ve vnímání a pojímání famy. Fama jako reputace je ve francouzštině častější spíše pod pojmem renomée, bonne renomée (tj. bona fama), protikladem je disfame. Philippe de Beaumanoir ve své knize práva z roku 1283 píše na několika místech o bonne renomée a jak může být ztracena [Akehurst 2003: 75]. Beaumanoir trval na tom, že svědek musí svědčit o tom, co sám viděl, a ne o tom, co kde slyšel z druhé ruky. Akehurst uvádí, že v knihách 13. století toho o svědcích a jejich svědectvích není mnoho napsáno, vyjma Beaumanoira.

Svědectví se rozlišovalo podle osobních názorů svědků ohledně podané sociální identity obžalovaného a mezi svědectvím těch svědků, kteří se koncentrovali na to, jak byl jedincův status nahlížen skrze publicu famu et vox. Ta byla popisována jako osobní pověst a informace či obecné mluvení o ní, tedy nejen to, jak je sociální identita jedince popisována druhými, ale taktéž, jak druzí slyší další o témže jedinci hovořit. Svědectví tak bylo založeno na tom, co svědek sám viděl nebo si myslel, ale také bylo především o obecném mínění, o obžalovaného cti či pověsti. Fama byla ale překvapivě neúčinným důkazem u soudů týkajících se vyšších statusů. V tomto případě Vallerani pojímá termín fama publica jako jakousi záruku privilegovaných osob, že nebudou v př́ípadě jakéhokoliv porušení zákona či trestu mučeny na základě pouhého rozhodnutí soudu. Sloužila tak osobám privilegovaným, které měly status privilegium bone fame, jenž jim zaručoval, že nemohou být mučeny jen $z$ rozhodnutí soudu bez př́mého a hmatatelného důkazu.

Při zkoumání záznamů z francouzského vězení ze 14. století Cassidy-Welsch [2002] nalezla prameny hovořící o vox et fama est $\mathrm{v}$ různých svědectvích u soudu. Tento výraz byl překládán jako něco, co bylo řečeno či rozhlašováno. V širším a častějším smyslu slova však výraz vox et fama znamenal věrohodnost, která byla myšlena ve smyslu věrohodnosti vzešlé $\mathrm{z}$ veřejného či kolektivního vědomí nebo událostí. Valleraniho definice termínu publica fama et vox [Vallerani 2012: 109] je taková, že znamená mínění, které vyrůstá ihned na místě činu, kde byl čin spáchán. Publica fama et vox obecně také znamenala pověst jedince, osobní reputaci, rovněž tak fama communis [Donahue 2008]. Někteří komentátoři civilního práva popisovali famu jako obecné mínění, které bylo založené na 
faktech, a požadovali, at svědek v soudním procesu deklaruje, že obecný názor byl vyjádřen většinovou veřejností. Vox et fama nebyl výjimečným výrazem v inkvizičních nebo jiných zákonných dokumentech a často se ho používalo jako součást závěrů ve výkazních listech různých stížností, které předcházely výpovědím.

Ve 13. a 14. století se porota informovala ve věci obžalovaného sama, spoléhala na to, co jí kdo řekl či co se od kohosi dozvěděla. Verdikty byly vynášeny na základě toho, co bylo považováno za obecně známé, za publicu famu, to se zřejmě změnilo v 15 . století, kdy porotci už nezískávali informace sami, nevyměňovali si je pouze mezi sebou, ale poslouchali a porovnávali jim představené důkazy. Člen poroty také nemohl pocházet z místa bydliště obžalovaného a také nemohl sedět ve více porotách najednou [Shapiro 1991: 33]. Členové soudní poroty neměli dostatečné vědomosti k tomu, aby posoudili př́pad bez důkazů a veškeré relevantní informace dostávali z několika zdrojů, a to z prrímých důkazů, z výslechů obžalovaného, z jeho obhajoby, z otázek soudce atd. Při rozhodování také brali v potaz důvěryhodnost vlastní obhajoby [Shapiro 1991: 6]. Jak společnost začala být komplexnější a mobilita vzrůstala, jak občanské, tak trestní poroty byly méně familiární s fakty a začaly čím dál tím více spoléhat na svědectví přímých svědků a na dokumenty, které už musely být vyhodnocovány na základě pravdivosti a přesnosti.

\section{Od famy $\mathrm{k}$ fámě}

Do 15. století se tedy můžeme setkat s famou především jako s důležitou právní kategorií ve smyslu obecného mínění. Naopak v 16.-17. století lze vypozorovat pojímání famy jako antické bohyně ztělesňující pověst, což jistě souviselo s prríchodem renesance a jejím návratem k antickému umění, to lze zvláště vysledovat ve výtvarném umění, literatuře, v rytinách přebalů knih aj. Dochází tak k jasnému oddělení pojímání rozličných variant významů famy, které se objevuje až koncem středověku, respektive znatelně přichází s renesancí a jejím návratem $\mathrm{k}$ antice.

Fama se již byla používala spíše pro označení pověsti o určitých jedincích. Tak například Fama Fraternitatis (1614), neboli Rozenkruciánská pověst, Fama exequialis, Powěst dobrého gména Urozeného Pána Pana Wratislawa z Mitrowic (1613), Fama posthuma Johanis Nepomuceni (1641) dokládají význam famy jako pověsti, příběhu o životě jedince. Pojímání famy jako důležité a často i stěžejní kategorie v právu či v komunitních vztazích postupně vymizelo a působnost a vnímání famy se stejně jako samotný pojem změnilo. Co se tedy stalo, že začala být pojímána úplně odlišně? Jak se z famy stala fáma?

Historie moderní famy začíná až s nástupem renesance, kdy byl pojem fama používán pro diskurzy politické reprezentace, tj. fama sloužila jako výraz pro věhlasnou pověst, slávu či širokou známost (odtud poté pramení i dnešní anglický výraz fame, famous ve smyslu široké známosti mezi mnoha lidmi). Fama byla brána jako široce rozšířená dobrá pověst, sláva, byla i tak zobrazována, především v ikonografii a výtvarném umění, a to od 15 . století jako alegorická personifikace, od 17. století jako elegantně oblečená žena (zvláště ve výtvarném umění). Neubauer [1999: 69-71] poukazuje na stěžejní význam katalogu různých forem mýtů Iconology Cesara Ripa (1669), jenž jako standardní ikonografický archiv doby poukazuje na velké historické a literární dimenze rozdílných materiálů a motivů, čímž poskytuje data pro kartografii antického mytologického světa. Zde se jasně a explicitně rozlišuje mezi Rumore a Famou. Rumore zobrazuje muže, válečníka, s přilbou na 
hlavě, bradkou, svalnatým tělem, držícího v ruce šípy, přičemž jeho postoj naznačuje, že je připraven ihned zakročit proti protivníkovi. Fama je zobrazena jako okřrídlená mužská postava kráčící vpřed, v jedné ruce drží žezlo, ve druhé koně. Oba obrazy podle Neubauera ukazují rozdílné dimenze antických konceptů fámy. Latinská fama, znamenající fámu i pověst, je v ikonologii rozdělena na dvě figury, což autor vysvětluje jako proměnu vnímání a pojímání fámy, která je ovlivněna kulturním kontextem a jejíž zobrazování je historickou signifikací.

Ona fama, která ve středověku označovala obecné mínění, slávu, čest, reputaci, pověst, hodnocení, se proměňuje v tom smyslu, že už neslouží jako souhrnné označení, ale získává novou hodnotu a označuje něco jiného, mění se konotace a asociace spojené s jejím významem, tedy nyní už označuje pouze pověst. Pro označení obecného mínění začíná převažovat pojem opinio ${ }^{17}$, pro označení fámy se přechází k použivání pojmu rumor [Evans 2002: 124].

Jako stěžejní se v proměně pojímání famy zdá být změna v právním systému, zvláště pak důkazního řízení. Praktiky ve 2. polovině 14 . století již poukazují, že soudy se pomalu přestávají spoléhat výlučně na svědkovu výpověd', což ve 13. století nebylo možné, tehdy soudce zahajoval stání tím, že shrnul výpovědi a výslechy svědků z místa činu, aby potvrdil skutečnost činu a jméno podezřelého. Avšak nyní trest obviněnému porotci nestanovovali již na základě osobně získaných informací od dalších lidí, ale zakládali své soudy na informacích podaných soudem a na prrímých svědectvích a nezpochybnitelných důkazech, které se shromaždovaly a vyhodnocovaly podle předem daných kritérií. Od vox dei, tedy hlasu božího, který ztělesňovaly ordály, se soudní systém klonil k vox populi, hlasu lidu, který zastávaly soudní poroty či očití svědci. Dále je znatelný posun v pojímání důvěryhodnosti samotným soudem, nebot důraz se posouvá od spolehlivosti jedince k důvěryhodnosti faktů. S tím souvisí i posun famy (ve smyslu cti, osobní pověsti) od něčeho čistě komunitního k individuálnímu.

Člověk se dříve neorientoval podle svých vlastních znalostí a schopností, ale podle orientace a tradic společenství, podle kolektivních dispozic a představ, z nichž také čerpal vlastní přesvědčení o pravdivosti nebo lživosti. Pravda byla to, co za pravdu považovala komunita [Gurevič 1978]. Posunem se však fama dostala do čistě jedincova pưsobení a jeho vlastního vlivu. Jedinec se sám hájil, sám utvářel a udržoval vlastní famu, namísto toho, aby zdrojem jeho famy byla komunita, vztahy v ní a svědectví druhých. Fama jako sít lokálních kolektivních znalostí ustupovala do pozadí, již v 15. století nesloužila jako přímý a plný důkaz a byla relevantní jen u některých deliktů. Italský kriminalista Giulio Clarus ve své knize píše, že fama ze soudních síní v 16. století úplně vymizela [Bettoni 2010].

Pokud byl středověk bohatý na procesy, kde hlavní roli hrála fama jako lokální sít znalostí o jedinci, nyní se soudní procesy stále více vyznačují bránění se proti újmě na cti, tzv. defamatizaci ${ }^{18}$. Ty naplno propukají koncem středověku či počátkem rané-

17 Proměnu vnímání pojmu fama na počátku 16. století lze vysledovat v myšlení Machiavelliho, jenž tento výraz nepojímá jako ve středověku, tedy jako kolektivní mínění, ale pouze jako osobní pověst, at dobrou nebo špatnou. Vưbec o něm tedy nemluví jako o něčem stěžejním ve smyslu „veřejného mínění, pro což používá např́klad commune opinione v Rozpravách o prvních deseti knihách Tita Livia (I.57).

18 Dülmen poukazuje na zvyšující se počet procesů proti nactiutrhání zejména od 16 . století. Nicméně poměrně značný nárůst soudů tohoto druhu lze vysledovat již ve 2. polovině 15. století v Anglii, který se ještě více stupňuje v následujících stoletích [srov. Kamensky 1999; Capp 2004]. 
ho novověku a jejich počet je enormní. Dülmen uvádí, že tehdy nic nemělo větší cenu než dobrá pověst, bezúhonnost a čest. I tehdy byla pověst předpokladem pro dobré sousedské vztahy, pracovní úspěchy, mezilidské vztahy a také pro získání lepšího místa a zvýšení statusu. Pověst se soustředila kolem týchž věcí jako ve středověku, avšak byla čistě v poli působnosti jedince, který si ji bránil a chránil. Avšak i zde pro čest jednotlivce bylo určující mínění ostatních. Důvodem, proč měla pověst takovou váhu, byly škodlivé následky klevet a pomluv; vše muselo být vyřčeno a nic nezůstalo skryté. Klevetění bylo součástí zábavy, všem zaručovalo soudržnost. (...) Nikdo si nedovolil nevěnovat klepům pozornost [Dülmen 2003: 8].

Další rolí je jistě explicitní označování určité informace za fámu, tedy nyní, od 16. století, je fáma jasně ohraničena a stejně tak vnímána, do této doby to byla relevantní informace, kterou od skutečné fámy nešlo odlišit. To jistě souvisí s postupným vymezováním soukromé a veřejné sféry, kvưli čemuž existovala tendence mluvit na správném místě a dávat si pozor na jazyk. Ve středověku bylo mluvení, které mělo hodnotu, sociálně konstruováno a začínalo být ohraničováno morálními a právními restrikcemi a nařízení$\mathrm{mi}^{19}$, které byly řízeny centralizovanou společností. Důvěra v takto regulované mluvení postupně ustupovala a panovalo podezření ohledně jeho spolehlivosti. Vědělo se, že na veřejnosti se muselo mluvit korektně, takže lidé přestávali věřit tomu, že je to pravdivé, a vznikalo podezření ohledně důvěryhodnosti toho, co se říká. To způsobovalo nejen strach $\mathrm{z}$ osobních hovorů na veřejnosti, ale bezpochyby to vyvolávalo i změny ve způsobu, jak lidé vnímali sami sebe i druhé, minimálně pak právě na veřejnosti. Větší sociální komplexita a zvyšující se institucionalizace, která byla doprovázena nárůstem moci státu, pravděpodobně působila na větší zprostředkovávání ve vztazích mezi lidmi spolu s oficiální obezřetností ohledně mluvení, tedy - lidé si čím dál tím více dávali tzv. pozor na jazyk [Fenster - Smail 2003: 214].

Př́iklad této skutečnosti uvádí například Kuehn [2003], když ukazuje na to, že existoval rozdíl mezi famou a fámou, přičemž fáma, př́ípadně i jí podobná kleveta, byla zejména ženskou doménou. Již jsme poukázali na to, že vliv famy u soudů v 15. století klesal, přičemž vymizel až ve století 16., naopak hlavní roli fama, př́padně již fáma, měla na ulicích a obecně v mezilidské komunikaci. Na ulicích byla fama klevetou, pověstí, obecným věděním, ale u soudu byla statusem s právními důsledky. Kuehn tak poukazuje na to, že v italských renesančních městech existovala fama sociální a fama právní, mezi nimiž nebyla přímá a znatelná spojitost, $\mathrm{v}$ čemž lze spatřovat znatelný posun od středověkého vnímání, nebot tato problematika tam byla slučována.

Autoři 16. století také silně reflektují tzv. hříchy jazyka, hříchy mluvení. Jazyk je tak pokládán za zdroj hříchu a nástroj satana. Na jednu stranu je pro společnost př́inosný, ale zároveň ji může ničit. Jedním z takovýchto hříchů jazyka bylo i šíření fám. Ty se často týkaly majestátu nebo politiky státu a v tu chvíli nastávala nutnost jejich právní regulace. Šíření fám proti králi mohlo být považováno i za velezradu a za šíření fám proti vrchnosti se mohlo jít i do vězení. Proti řečem takového druhu existovala v Anglii

19 Tak např́iklad v roce 1555 byla v Anglii zavedena nová legislativa, která navrhovala tvrdé tresty či pokuty za klamavé a pomlouvačné informace, fámy či průpovídky proti vládě, lordům, králi a jeho rodině [Fox 2000: 337]. 
mocná legislativa ${ }^{20}$ [Cressy 2010]. Adam Fox [2000: 405] ukázal, že do konce 18. století autority státu i církve opakovaně varovaly lid, aby se vyvaroval veškerých politických debat, protože takovéto záležitosti není s to pochopit. Koncem 17. století však podle Foxe lid takových varování nedbal a začal se o veškeré informace zajímat a také již hlasitěji vyjadřoval své mínění.

Podobný právní přístup k mínění lidu lze najít v té době i v českých zemích, kde byly zločiny páchány i „nepoctivými a velmi hanebnými řečmi a psaními“ [Vaněček 1970: 199]. Trestána byla také letáková agitace proti stavům a vládě. Vzhledem k tomu, že v době 16. století bylo časté vyjadřovat své názory na různých „zrádných, nešlechetných a hanlivých“ cedulích, vznikl zákon tzv. zrádných cedulí, přičemž se trestalo jak autorství, tak i rozšiřování, a to pod výhružkou trestu smrti [tamtéž: 200].

Zatímco monografie a prameny o fámě v dnešním slova smyslu jsou ve středověku dosti skoupé, ojediněle již v pozdním středověku, ale zejména v raném novověku je fámě věnována velká pozornost. Dokládá to značné množství publikací věnovaných tématu fám, klevet a samotné orální kultuře ${ }^{21}$ obecně [srov. Fox 2000, 2001; Capp 2004; Cressy 2010; Phillips 2007 aj.], přičemž v dobových pramenech nacházíme explicitně řečeno, že něco je/byla fáma.

Klevety, fámy, nepotvrzené informace měly ústřední roli při tvorbě obecného mínění i nadále, avšak ze soudních síní byly pro svoji nedůkaznost odstraněny, protože nadále zůstávaly něčím veřejným, nikoliv však právně relevantním. Fáma v dnešním slova smyslu samozřejmě existovala vždy, pročež byla vnímána jako hodnotná relevantní informace, teprve s přelomem 15.-16. století začala být jasně ohraničována a vnímána jako fáma.

\section{Závěrem}

Stat představila vztah fám a obecného mínění a jeho vývoj od antického Říma až $\mathrm{k}$ ranému novověku. Takto dlouhé období bylo zvoleno záměrně, a to kvưli výrazu fama, výrazu označujícímu (nejen) obecné mínění, ale i fámu. Pozornost se proto soustředila na stěžejní výrazy, které byly s těmito jevy spojeny - fama, existimatio, rumor, sermo či opinio. Zvláštní pozornost byla věnována rozlišování mezi famou a existimatiem, které vyjadřovaly obecné mínění především vládnoucích vrstev a jež byly vnímány jako spolehlivé a hodnotné, a rumor či sermo, které označovaly nespolehlivé a nehodnotné mínění plebsu. Důležitým prvkem pro označování, pojímání a především hodnocení

20 Například v roce 1642 nabyl platnosti Zvláštní zákon o nezákonném tisku a o potlačování všech lživých a pohoršlivých tiski̊.

21 I na počátku novověku probíhala výměna informací zejména ústně. Ačkoliv vzrůstal vliv tištěných médií, většinová společnost nadále komunikovala primárně ústně a přestože měla přístup $\mathrm{k}$ psaným textům, raději získávala informace skrze ústní komunikaci. Samozřejmě lze zájem o moc jazyka nalézt i dříve, především v církevních a světských textech. Sandy Bardsley [2003: 147] tak např́klad zjistila, že v letech 1275-1276 anglické předpisy důrazně zakazovaly šírit fámy a pomluvy týkající se krále nebo př́ílušníků vyšší třídy. Edwin Craun [1997] poukázal na to, že ve 13. a 14. století můžeme doložit zvyšující se zájem o moc mluvení, zvláště v kostelech. Svůj zájem zaměřil na církevní a sekulární texty následujících století. Ve 14. století byl diskurz šířen nejen od kleriků k laikům, ale také mezi těmi, co neuměli číst a mezi neelitou. Craun dále ukazuje, že pozdně středověký diskurz o dábelském mluvení byl ustanoven v kostele. Během pozdního středověku kompetence soudů, co se týče zločinů mluvení, byly upevňovány sériemi zákonů proti zradě a proti fámám a lžím o aristokracii. Tyto zákonem dané předpisy se staly populární mezi běžnými lidmi. 
mínění hrál vztah elity k plebsu. Ze skupinek plebsu - circuli - mívala elita vždy strach, a tak měla zvláště pro jeho mínění specifické označení a považovala je za fámy.

Mínění v antickém Rímě bylo však považováno i za nebezpečné a nestálé. Veřejně činní politici a řečníci byli nuceni zaobírat se náladami lidu a sledovat proměny v jeho mínění, které bylo manifestováno jak v reakcích na veřejných shromážděních, tak i ve fámách a klevetách, které se šírily po městě. Klevety a fámy hrály dưležitou roli i ve formování mínění středověkého lidu. To sehrávalo zásadní roli především u soudních přelíčení. Obecné mínění bylo jak důležitým hlasem lidu, tak i strážcem obecné shody, nositelem sociálních norem a institucí, který dohlížel na sociální adaptaci obyvatelstva.

Pojímání výrazu fama převzalo i středověké právo, v němž jako obecné mínění hrál velmi významnou roli především v soudních procesech, sloužil jako kolektivní hodnocení či lokální sít znalostí a ovlivňoval tak život středověkých komunit i jedinců. Fama obecné mínění označovala až do 15 . století, nebot právě tehdy její moc upadá. Stat' spatřuje důvody této změny v proměně soudního systému, zejména důkazního řízení, poté ve stále znatelnější individualizaci jedince a ve stále větší distinkci mezi soukromou a veřejnou sférou.

\section{Literatura}

Akehurst, F. R. P. [2003]. Good Name, Reputation, and Notoriety in French Customary Law. In. Fenster, Thelma - Smail, Daniel Lord. Fama. The Politics of Talk and Reputation in Medieval Europe. Ithaca: Cornell University Press, s. 75-94.

Bardsley, Sandy [2003]. Sin, Speech, and Scolding in Late Medieval England. In. Fenster, Thelma - Smail, Daniel Lord. Fama. The Politics of Talk and Reputation in Medieval Europe. Ithaca: Cornell University Press, s. 145-164.

Bettini, Maurizio [2006]. Mythos/Fabula: Authoritative and Discredited Speech. History of Religions 45 (3): 195-212.

Bettoni, Antonella [2010]. Fama, shame punishment and metamorphoses in criminal justice. [online]. Dostupné z: <http://www.researchgate.net/publication/44024774_Fama_shame_punishment_and_metamorphoses_in_criminal_justice_(Fourteenth-Seventeenth_centuries) $>$ [cit. 23. ledna 2014].

Botelho, Keith [2009]. Renaissance Earwitnesses. Rumour and Early Modern Masculinity. Palgrave Macmilian.

Bowman, Jeffrey [2003]. Infamy and Proof in Medieval Spain. In. Fenster, Thelma - Smail, Daniel Lord. Fama. The Politics of Talk and Reputation in Medieval Europe. Ithaca: Cornell University Press, s. 95-117.

Capp, Bernard [2003]. When Gossips Meet: Women, Family, and Neighbourhood in Early Modern England. Oxford: Oxford University Press.

Craun, Edwin [1997]. Lies, Slander, and Obscenity in Medieval English Literature: Pastoral Rhetoric and the Deviant Speaker. Cambridge: Cambridge University Press.

Cressy, David [2010]. Dangerous Talk. Scandalous, Seditious, and Treasonable Speech in Pre-Modern England. Oxford: Oxford University Press.

Donahue, Charles [2008]. Law, Marriage, and Society in the Later Middle Ages. Cambridge: Cambridge University Press.

Dülmen, Richard [2003]. Bezectní lidé. O katech, děvkách a mlynářích. Praha: Dokořán.

Edwards, Catharine [1993]. The Politics of Immorality in Ancient Rome. Cambridge: Cambridge University Press.

Evans, Gillian [2002]. Law and Theology in the Middle Ages. London, New York: Routledge.

Fenster, Thelma - Smail, Daniel Lord [2003]. Fama. The Politics of Talk and Reputation in Medieval Europe. Ithaca: Cornell University Press. 
Fox, Adam [2000]. Oral and Literate Culture in England, 1500-1700. Oxford: Oxford University Press. Geertz, Clifford [1983]. Local Knowledge: Fact and Law in Comparative Perspective. In. Local Knowledge. Basic Books, s. 167-234.

Greenidge, A. H. J. [1894]. Infamia. Its Place in Roman Public and Private Law. London: Henry Frowde. Gurevič, Aron [1978]. Kategorie středověké kultury. Praha: Mladá fronta.

Habinek, Thomas [1998]. The Politics of Latin Literature. Writing, Identity, and Empire in Ancient Rome. New Jersey: Princeton University Press.

Helmholz, Richard [2001]. Ius Commune in England: Four Studies. Oxford: Oxford University Press.

Justiniánské instituce [2010]. Praha: Karolinum.

Kamensky, Jane [1999]. Governing the Tongue. The Politics of Speech in Early New England. Oxford: Oxford University Press.

Kapferer, Jean-Noël [1992]. Fáma nejstarší médium světa. Praha: Práce.

Kincl, Jaromír - Urfus, Valentin [1990]. Římské právo. Praha: Panorama.

Livingston, John [1962]. Infamia in the Decretists. From Rufinus to Johannes Teutonicus. University of Wisconsin.

Machiavelli, Niccolò. 1986. Rozpravy o prvních deseti knihách Tita Livia. In. Úvahy o vládnutí a vojenství. Praha: Naše vojsko, s. 166-355.

Menache, Sophia [1991] The vox dei: communication in the middle ages. New York: Oxford University Press.

Michal, Jaroslav [1967]. Dějiny k pramenům poznání kanonického práva. Praha: Kímskokatolická Cyrilometodějská bohoslovecká fakulta.

Mirror of the Saxons (Sachsenspiegel) [online]. Dostupné z: $<\mathrm{http}: / /$ www.wdl.org/en/item/11620/\#q=sachsenspiegel\&qla $=\mathrm{en}>$ [cit. 27. ledna 2014].

Mucciarelli, Roberta [2013]. Neighbourhood, Rumors, and Fama: A Piece of Judiciary History from Thirteenth-Century Prato. In. Israels, M. - Waldman, L. Renaissance Studies in Honor of Joseph Connors. Florence: The Harvard Center of Italian Renaissance Studies, s. 199-207.

Neubauer, Hans-Joachim. 1999. The Rumour: A Cultural History. London, New York: Free Association Books.

Noelle-Neumann, Elizabeth. 1993. The Spiral of Silence: Public Opinion - our Social Skin. Chicago, London: University of Chicago Press.

O’Neill, Peter [2003]. Going Round in Circles: Popular Speech in Ancient Rome. Classical Antiquity 22 (1): $135-176$.

Pease, Arthur (ed.) [1955]. M. Tulli Ciceronis. De Natura Deorum. Cambridge: Harvard University Press.

Phillips, Susan [2007]. Transforming Talk. Problem with Gossip in Late Medieval England. Pennsylvania State University Press.

Pina Polo, Francisco. 2010. Frigidus Rumor: The Creation of a (Negative) Public Image in Rome. In. Turner, Andrew - Chong-Gossard, K. O. - Vervaet, Frederik (eds.). Private and Public Lies. The Discourse of Despotism and Deceit in the Graeco-Roman World. Boston, London: Brill, s. 75-90.

Potter, D. S. [1999]. Political Theory in the "Senatus Consultum Pisonianum". The Americal Journal of Philology 10 (1): 65-88.

Quintilianus, Marcus Fabius [1985]. Základy rétoriky. Praha: Odeon.

Rosnow, Ralph - Fine, Gary Alan [1976]. Rumor and Gossip: The Social Psychology of Hearsay. New York: Elsevier.

ze Sevilly, Isidor [2003]. Etymologiae V. Praha: Oikúmené.

Shapiro, Barbara [1991]. Beyond Reasonable Doubt and Propable Cause. Historical Perspectives on the Anglo-American Law of Evidence. Berkeley: University of California Press.

Shibutani, Tamotsu [1966]. Improvised News: A Sociological Study of Rumor. Indianapolis: Bobbs Merrril.

The Visigothic code (Forum judicum) [online]. Dostupné z: <http://libro.uca.edu/vcode/visigoths.htm> [cit. 24. ledna 2014].

Vallerani, Massimo [2012]. Medieval Public Justice. Washington: Catholic University of American Press.

Vaněček, Václav [1970]. Dějiny státu a práva v Československu do roku 1945. Praha: Orbis.

Vaněček, Václav [1976]. Déjiny státu a práva v Československu do roku 1945. Praha: Orbis.

Vivo, Filippo de [2009]. Information and Communication in Venice: Rethinking Early Modern Politics. Oxford: Oxford University Press. 
Wickham, Chris [1998]. Gossip and Resistance among the Medieval Peasantry. Past \& Present (160): 3-24. Wickham, Chris [2003]. Fama and the Law in Twelfth-Century Tuscany. In Fenster, Thelma - Smail, Daniel Lord. Fama. The Politics of Talk and Reputation in Medieval Europe. Ithaca: Cornell University Press, s. 15-26.

Yavetz, Zvi [1974]. Existimatio, Fama and the Ides of March. Harvard Studies in Classical Philology (78): $35-65$.

Kateřina Soukalová vystudovala historickou sociologii na Fakultě humanitních studií Univerzity Karlovy v Praze. V současnosti působí jako doktorandka v témže oboru. Zabývá se historickou sociologií mínění, problematikou fám, klevet a dezinformací či obecně sociální psychologií komunikace. 